Vol. 4, No. 1, January 2016

Jurnal llmial

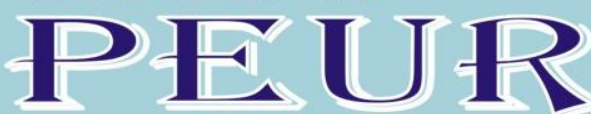

Media Kajian Ilmiah Sosial, Politik, Hukum, Agama dan Budaya
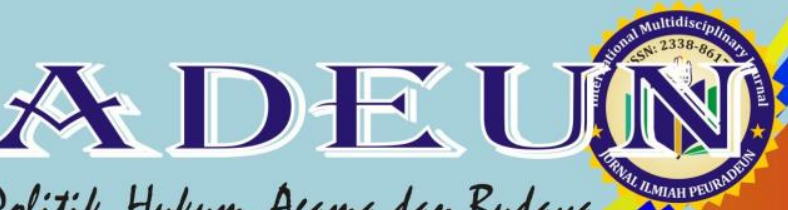


\title{
(1) \\ PERFORMANCE OF EMPLOYEES AND IMPACT ON PROMOTION OF POSITION
}

\author{
Sarboini \\ Faculty of Economics, Serambi Mekkah University, Banda Aceh, Indonesia \\ E-mail: sarboinise@gmail.com
}

Received: Jun. 11, 2015

Accepted: Sept. 25, 2015

Published: Jan 21, 2016

Article Url: https://journal.scadindependent.org/index.php/jipeuradeun/article/view/89

\begin{abstract}
Performance appraisal is an activity controlling the management of a company. This study is an empirical study that aims to determine the effect of performance appraisal and promotion of their work motivation and their impact on employee performance at Serambi Mekkah University. The research was conducted at Serambi Mekkah University. The populations in this study were all employees at Serambi Mekkah University which amounts to 105 people. Data was collected by distributing questionnaires. Primary data were analyzed with path analysis with the aid of SPSS software. The results showed that, performance appraisal and significant positive effect on work motivation. Performance appraisal and promotion of positive and significant effect on the performance of employees at Serambi Mekkah University. In addition, work motivation can enhance the role of employees in Serambi Mekkah University.
\end{abstract}

Keywords: Performance Appraisal, Promotion, Motivation, Employees 


\section{A. Introduction}

A College has become one of the institutions which is participating in expanding the government mission in the field of education and teaching which include tasks in the field of scientific research and dedication to the community. The one of goals of the universities according to PP. No. 60 of 1999 Section 2 is to prepare students to be members of the community who have the academic and professional capability to implement, develop and / or enrich the science, technology and / or art.

Employees as beings of human resources at the college, be adaptive and tolerant party in supporting the implementation of quality teaching and learning in higher education. However, the campus environment change with a wide range of dynamics in line with the rising expectations of employees, it is often influence their behavior in their workplace of some existing behavior. The motivation becomes a complex problem, and not easy to identify the core problem and solve it (Griffin, 2004: 38).

The motivation of employee in the college becomes interesting to be discuss, first rising expectations and desires of employees who are not always able to be met equally by the college. Second the goals, attitudes and expectations of different employees. Third, the growing of tendency of employees to seek pleasure and avoid trouble in the work, thus employee motivation in college is still questionable.

These conditions are also occurring at University of Serambi Mekkah Aceh. There are not all employees are motivated by wage/ salary that they receive in their work. However there are many other factors that influence employee motivation at the university. Promotion and performance appraisal be several factors that help to improve employee motivation at Serambi Mekkah University.

Promotion is an opportunity to develop and progress to encourage employees to better or more eager to do a job within the organization or company. By the target of promotion, definitely employee will feel appreciated, cared for, and recognized capabilities needed work by the college management organizations so that they will produce the higher output and will enhance the loyalty (faithfulness) at the college. Therefore, 
leaders have to realize the importance of the promotion in improving employee performance should be considered objectively. If there is the leaders has been aware of and consider, then the company will avoid the problems that delay the improvement of output and it could unfavorable the company such as: employee dissatisfaction, complaints, lack of morale, declining labor discipline, and many of them absent or even problems strike work.

To determine the fully remuneration awarded to an employee for his or her work, and then an agency must have something appropriate remuneration system. A mechanism to be able to determine the appropriate remuneration for a job promotion is the employee performance evaluation.

One element of performance appraisal and promotion is the requirement for the employee, where the employee to work, the company can guarantee job security and career coaching certainty, (Sutrisno, 2009: 133). Employees work not only for one or several days, but they expect to work until retired, so that they need the necessary guarantees for future careers, both guarantee the promotion of position of authority, the rank promotion and provision of opportunities for potential float (Sutrisno, 2009: 128).

But in reality there is no visible guarantee and certainty of career is perceived by employees at Serambi Mekkah University Aceh. The less parts of development work and new areas of work within the organizational structure of Serambi Mekkah University as well as the length of the cycle of change of the position of his or her career for several positions where there are very limited in number. This conditions then also will make the performance assessment is not good implemented.

\section{B. Method}

This research was an empirical study which uses a kind of explanatory research with cross sectional approach. The sample of this research is the total population of the Serambi Mekkah Univerisity Aceh, and the population would be all employees of Serambi Mekkah University were105 participants. And the data collection techniques have done by distributing questionnaires to all employees of Serambi Mekkah 
University Aceh. While the data analysis done by using SPSS, because the aims of this research to determine the effect of the work performance assessment and promotion toward the motivation of employee at Serambi Mekkah University Aceh.

\section{Research Finding and Discussion}

The analysis of employees' perception of the work performance assessment and the promotion of position authority needs to be done in this research. The data collected in this research by using a questionnaire. The questionnaire consists of four (six) questions about job performance, six (three) questions about the promotion, five (5) questions about the motivations and 6 (six) questions about the performance. The questions used enclosed design that is the question in the form of options that have been provided.

\section{Table 1: The Effect of Job Performance Assessment and the Promotion Motivation of Work}

\begin{tabular}{llcccc}
\hline Model & \multicolumn{2}{c}{$\begin{array}{c}\text { Unstandardized } \\
\text { Coefficients }\end{array}$} & $\begin{array}{c}\text { Standardized } \\
\text { Coefficients }\end{array}$ & $\mathrm{t}$ Sig \\
\hline & B Std. Error & Beta & \\
\hline Constants & 1.705 & 305 & & 5.59 .000 \\
\hline Performance assessment $\left(\mathrm{X}_{1}\right)$ & 260 & 075 & 290 & 3.45 .001 \\
\hline Promotion of employees $\left(\mathrm{X}_{2}\right)$ & 324 & 065 & 420 & 4.99 .000 \\
\hline
\end{tabular}

The results output of SPSS in the Table: 1 it can be made that the line of linear equation, $Y=0,290 X 1+0,420 X 2$. First, the regression coefficient beta for the assessment of job performance is 0.290 , explaining each of the increase in the activity of the job performance assessment of the single unit, it will be able to increase employee motivation at Serambi Mekkah University Aceh amounted to 0,299 . Thus if the assessment work performance can be highly improved, then the employee motivation at the Serambi Mekkah University would be better. Second, the regression coefficient beta for the promotion of employees is 0.420 it explains if the increase in promotional activities of employees of the single unit, it will be able to improve employee motivation at the Serambi Mekkah University Aceh by 0.420 . Thus if the activity in the 
work performance assessment increase well, then employee motivation at Serambi Mekkah University would be better.

Tjahjono (2007: 116) defines that the comparison of reference of proportions is a particular person are prepared by the concerned employee and which has a position that can be comparable. If employees prepared outputinput ratio is obtained together with others, then the employees will assume that similar conditions. However, if the ratio is not the same, the employee will feel unfairly treated. In this research, it can be said that most of employees have gained the perception that compensation equivalent to the compensation obtained by the business colleagues, work experience, self-efficacy, and the results of the same performance. Handoko (2012: 135) says that one of the benefits of job assessment is to help determine the wage increases, bonuses, promotions and other forms of compensation. The results of job performance assessment has provided benefits, so that employees prepared the results performance assessment it has been very influential on compensation in the form of salary increases and promotions that they obtained.

\section{Table 2: Effect of Job Performance Assessment and Promotion On Employee Performance}

\begin{tabular}{|c|c|c|c|c|}
\hline Model & $\begin{array}{r}\text { Unstand } \\
\text { Coeffic }\end{array}$ & $\begin{array}{l}\text { rdized } \\
\text { ients }\end{array}$ & $\begin{array}{c}\text { Standardized } \\
\text { Coefficients }\end{array}$ & t Sig \\
\hline & B Std. & Error & Beta & \\
\hline Constants & 1,565 & 0,303 & & 5.158 \\
\hline Performance assessment $\left(X_{1}\right)$ & 0,394 & 0,075 & 0,435 & $5,258 \quad 0,00$ \\
\hline Promotion of employees $\left(X_{2}\right)$ & 0,234 & 0,064 & 0,300 & 3,630 \\
\hline
\end{tabular}

The results output of SPSS in the Table: 2 it can be made line of linear equations is as follows: $Z=0,435 \times 1+0,300 \times 2$.

The equation above explains that, regression coefficient beta for performance assessment of $=0.435$ explain each of the increase in the activity of job performance assessment of the single unit, it will be able to increase the performance of employees at Serambi Mekkah University Aceh amounted to 0.435. Thus if the work performance assessment can be improved, the performance of employees at the Serambi Mekkah University would be better. And then, regression coefficient beta for the promotion of employees 
amounted $=0.300$ explain if the increase in promotional activities of employees of the single unit, it will be able to increase the performance of employees at the Serambi Mekkah University Aceh amounted to 0.300. Thus if the promotional activities can be improved, the performance of employees at Serambi Mekkah University would be better.

The value standardized coefficients significant effect on the work motivation. This is because employees have the perception that compensation has been fair. Schuler and Jackson (1999) reveals that the concept of justice refers to how compensation is believed to be employees deserve it get compared to how adequate compensation earned by others in the company. The employees will compare between they have given to the company and that they receive from the company. If they consider fair admission or comparable then they will feel fair (as quoted in Muljani, 2002: 116).

The employees who use himself and someone else as a factor for comparison, is a subjective way. Tjahjono (2007: 22), states that the comparisons are conducted by employee is very confidential which prepare by each individual, so that the objectives, expectations, and perceptions of the input and output from one person to another can be differences. The results of the research showed that the employee motivations at Serambi Mekkah University Aceh are increased due to the compensation given are increasingly.

Tebel 3: The Results of Analysis Regression Effect of Work Motivation on Employee Performance

\begin{tabular}{|c|c|c|c|}
\hline Model & $\begin{array}{l}\text { Unstandardized } \\
\text { Coefficients }\end{array}$ & $\begin{array}{c}\text { Standardized } \\
\text { Coefficients }\end{array}$ & t Sig \\
\hline & B Std. Error & Beta & \\
\hline Konstanta & 1.486 & & .000 \\
\hline Motivasi kerja $(\mathrm{Y})$ & .595 & .588 & 7.381 .000 \\
\hline
\end{tabular}

The results output from SPSS in Table 3 can be made linear equation line is $Y=0,588 X+€ 1$. Beta regression coefficient for the motivation to work is equal to 0.588 explain each of the increase in work motivation of the single unit, it will improve the performance of employees at Serambi Mekkah University Aceh amounted to 0.588 . Thus if the employee motivation can be improved it would make the employee's performance will be better. 
Table 4: The Direct and Indirect Effect of Line Diagram

\begin{tabular}{|c|c|c|}
\hline \multirow{2}{*}{ No } & The effect in the variable & \multirow{2}{*}{ Model } \\
\hline & The direct effect & \\
\hline 1 & $\begin{array}{l}\text { The effect of performance assessment } \\
\text { on work motivation }\end{array}$ & $X_{1}-Y \quad 0,290$ \\
\hline 2 & $\begin{array}{l}\text { The effect of promotion employee on } \\
\text { work motivation }\end{array}$ & $X_{2}-Y \quad 0,420$ \\
\hline 3 & $\begin{array}{l}\text { The effect of assessment performance of } \\
\text { employee on work motivation }\end{array}$ & $X_{1}-Z \quad 0,435$ \\
\hline 4 & $\begin{array}{l}\text { The effect of employee promotion on } \\
\text { performance employee }\end{array}$ & $X_{2}-Z \quad 0,300$ \\
\hline \multirow[t]{2}{*}{5} & $\begin{array}{l}\text { The effect of employee motivation on } \\
\text { performance }\end{array}$ & $Y-Z \quad 0,588$ \\
\hline & The indirect effect & \\
\hline 1 & $\begin{array}{l}\text { The effect performance assessment on } \\
\text { performance through motivation of work }\end{array}$ & $\begin{array}{l}\mathrm{X}_{1-Y} \mathrm{Y}-\mathrm{Z} \\
(0,290 \times 0,58)=0,17\end{array}$ \\
\hline 2 & $\begin{array}{l}\text { The effect on performance of employees } \\
\text { through promotion of work motivation }\end{array}$ & $\begin{array}{l}\mathrm{X}_{2}-\mathrm{Y}-\mathrm{Z}(0,420 \times 0,58)=- \\
0,247\end{array}$ \\
\hline
\end{tabular}

The table above describes that the assessment of the achievements of work and promotion of employees at Serambi Mekkah University Aceh play a direct role in increasing employee motivation and performance of employees. Promotion of employees influence for motivation is much better than the role of the influence of performance appraisal with a higher coefficient. While the role of influence assessment of performance, is much better than the role of the influence of promotion of employees.

Nevertheless indirectly work motivation can enhance the role of the relationship between performance appraisal and promotion of employees with employee performance. Thus the role of motivation in enhancing the role of the relationship between the promotions of employees with the employee's performance is comparatively much better.

Performance is basically which is done or not done by the employee, so that there are many affects of contribution of what they have given to the institution or organization, including the quality of services presented (Efendy, 2002: 198). 
Table 5: The Testing of Hypotheses

\begin{tabular}{clrr}
\hline No & \multicolumn{1}{c}{ The effect in the variable } & Beta (R) & Sig \\
\hline 1 & $\begin{array}{l}\text { The effect of performance assessment on work } \\
\text { motivation }\end{array}$ & 0,290 & 0,001 \\
\hline 3 & $\begin{array}{l}\text { The effect of promotion employee on work } \\
\text { motivation }\end{array}$ & 0,420 & 0,000 \\
\hline 4 & $\begin{array}{l}\text { The effect of job performance assessment on } \\
\text { employee performance }\end{array}$ & 0,435 & 0,000 \\
\hline 5 & $\begin{array}{l}\text { The effect of employee promotion on } \\
\text { employee performance }\end{array}$ & 0,000 \\
\hline 6 & $\begin{array}{l}\text { The effect of employee motivation on } \\
\text { performance }\end{array}$ & 0,000 \\
\hline 7 & $\begin{array}{l}\text { The effect assessment of achievement of employee } \\
\text { on performance through motivation of work }\end{array}$ & \\
\hline
\end{tabular}

Based on the table above it can be concluded that, the job performance assessment has a positive effect and significant on the motivation of working with a Beta value of 0.290 and the level of significant 0.001 or $<0.05$. While the promotion of employees has positive effect and significant on the motivation of working with Beta value of 0.420 and the level of significant 0.000 or $<0.05$. This condition is correlation with job performance assessment and the promotion is part of efforts to meet the needs of humans. The general principle is applicable in humans namely after a requirement is satisfied then it will be appear the other needs. After the promotional needs of employees at a certain level have been met, then they will feel the need for the promotion leading to a higher level (Anoraga, 2009: 34). In addition, job performance assessment has a positive effect and significant on the performance of employees with a Beta value of 0.435 and the level of significant 0.000 or $<0.05$. This condition is caused by the performance assessment system is an integral part of a performance management activities to help develop employees. The system of performance assessment will be able to fulfill those functions in improving the quality of human resources as a whole (Darmawan, 2013: 186). 
Promotion of employees has a positive impact and significant on the performance of employees with a beta value of 0.300 and the level of significant 0.000 or $<0.05$. Meanwhile, the work motivation has a positive impact and significant on the performance of employees with a Beta value of 0.588 and the level of significant 0,000 or $>0.05$. This is because work efforts were described as achievement motivation to perform activities or tasks as well as possible will be able to achieve high performance. There is a positive relationship between motivation and achievement of the performance (Mangkunagara, 2005: 68). So the motivation of working is something that raises the morale. In psychological studies, motivation can be seen as a morale booster. The weakness and the stronger working motivation of employee will determine the size of job performance (Anoraga, 2009: 35).

In the performance assessment is also take an effect on the performance of employees at Serambi Mekkah University Aceh through the motivation to work with the Beta value of 0.171. Meanwhile, the promotion of employees has a positive effect on the performance of employees at Serambi Mekkah University Aceh through the motivation to work with the Beta value of 0.247.

This means that the promotion is strongly influenced by the performance of an employee. This is in accordance with the opinion of Sedarmayanti (2001: 55) that the good performance of employees will make a major contribution to the progress of the institution, in return of institution rewards in the form of promotions position authority for employees who have a good performance. The employee performance assessment carried out by the institution with an assessment team will assess each employee every month. At some institutions, the employees who have a good performance will be published annually, so as to spur competition among employees in improving their performance.

\section{E. Conclusion.}

The results of the research showed that the performance of employees have a positive impact on promotion, it means that if an employee's performance is good, then the employee can gain promotion. 
Performance assessment and promotion of employees at Serambi Mekkah University in Aceh plays a direct role in increasing employee motivation and performance of employees. The role of promotion effect of employees' work motivation is much better compared to the role of the effect of performance assessment with a higher coefficient. While the role of influence assessment of performance, is much better than the role of the influence of promotion of employees. Nevertheless indirectly, the work motivation can enhance the role of the relationship between performance assessment and promotion of employees with employee performance.

Performance is basically which is done or not done by the employee, so that there are many affects of contribution of what they have given to the institution or organization, it is also including the quality of services presented. This condition is inseparable from the work achievement assessment is a part of an effort the fulfillment of human needs.

\section{Bibliography}

Anoraga Pandji (2009). Psikologis Kerja, Jakarta: Rineka Cipta.

Birn J, Robin (2000). "The international Hand Book Of Market Research Techniques" In Association With The Market Research Society, London: Kogan Page.

Darmawan Didit (2013). Prinsip-prinsip Perilaku Organisasi, Surabaya: Pena Semesta.

Dessler, Gary (2008). Manajemen Sumber Daya Manusia. Edisi ke-7, Alih bahasa, Jilid 1 \& Jilid 2, Jakarta: Prenhallindo.

Edy, Sutrisno (2009). Manajemen Sumber Daya Manusia, Jakarta: Kencana.

Effendi, M. T. (2002). Manajemen Sumber Daya Manusia. Jakarta: Grasindo.

Griffin, Ricky W. (2004). Manajemen, Jakarta: Erlangga.

Handoko, T.H. (2012). Manajemen Perubahan dan Sumber Daya Manusia. Yogjakarta: BPFE. 
Lvina, E. (2015). The Role of Cross-Cultural Communication Competence: Effective Transformational Leadership Across Cultures. Jurnal Ilmiah Peuradeun, 3(1), 1-18.

Mangkunegara, A. P. (2005). Manajemen Suber Daya Manusia, Bandung: Rosda Karya.

Miftha, Thoha (2007). Manajemen Kepegawaian Sipil di Indonesia, Jakarta: Kencana.

Muljani, N. (2002). Kompensasi Sebagai Motivator Untuk Meningkatkan Kinerja Karyawan. Jurnal Manajemen dan Kewirausahaan. 4(2), 108-122.

Patimah, S. (2015). Pengaruh Rekrutmen dan Seleksi Terhadap Kinerja Kepala Madrasah Ibtidaiyah Negeri (MIN) Sekota Bandar Lampung. Jurnal Ilmiah Peuradeun, 3(1), 165-190.

Rivai Veithzal (2009). Manajemen Sumber Daya Manusia Untuk Perusahaan Dari Teori ke Praktek, Jakarta: Rajawali Pers.

Sastrohadiwiryo, Siswanto (2010). Pengantar Manajemen, Jakarta: Bumi Aksara.

Sedarmayanti (2001). SDM dan Produktivitas Kerja. Bandung: Mandar Maju.

Sopiah (2008). Perilaku Organisasi, Yogyakarta: Andi.

Tjahjono, H.K. (2007). Validasi Item-Item Keadilan Distributif dan Keadilan Prosedural: Aplikasi Structural Equation Modeling (SEM) dengan Confirmatory Factor Analysis (CFA). JMA, 18(2), 115-125.

ZA, T. (2014). Islamic Studies dalam Pendekatan Multidisipliner (Suatu Kajian Gradual Menuju Paradigma Global). Jurnal Ilmiah Peuradeun, 2(2), 211-234. 
